Vol. 17 (2008): 109-120.

\title{
Need for protein supplementation in the diet of growing dairy bulls fed total mixed ration based on moderate digestible grass silage and barley
}

\author{
Arto Huuskonen \\ MTT Agrifood Research Finland, Animal Production Research, FI-92400 Ruukki, Finland, \\ email:arto.huuskonen@mtt.fi \\ Hannele Khalili \\ MTT Agrifood Research Finland, Animal Production Research, FI-31600 Jokioinen, Finland \\ Erkki Joki-Tokola \\ MTT Agrifood Research Finland, Animal Production Research, FI-92400 Ruukki, Finland
}

\begin{abstract}
The objective of the present experiment was to study the need for the protein supplementation in the diet of growing dairy bulls (initial live weight $272 \pm 28.5 \mathrm{~kg}$ and final live weight $666 \pm 31.2 \mathrm{~kg}$, on average) fed total mixed ration based on moderate digestible grass silage and barley. The experiment comprised 24 Finnish Ayrshire bulls and 8 Holstein-Friesian bulls and included four treatments. The control diet (C) consisted of moderate digestible (653 g digestible organic matter in dry matter (DM) grass silage (450 g $\mathrm{kg}^{-1} \mathrm{DM}$ ), barley grain (275) and barley fibre (275) without protein supplementation. Three isonitrogenous experimental diets included also extra protein, i.e. (1) rapeseed meal (RSM) (supplementation $530 \mathrm{~g}$ DM per animal day $\left.{ }^{-1}\right),(2)$ wet distillers' solubles (WDS) (600 g) and (3) a mixture of barley protein $(90 \%$ of fresh weight) and wet distillers' solubles (10) (BPWDS) (480 g). In all isonitrogenous diets the crude protein content of concentrate increased from 137 to $150 \mathrm{~g} \mathrm{~kg}^{-1} \mathrm{DM}(9 \%)$ compared with the $\mathrm{C}$ diet. All bulls were fed total mixed ration ad libitum. The energy content of all diets was $11.6 \mathrm{MJ} \mathrm{kg}^{-1} \mathrm{DM}$. The live weight gain of the bulls tended to be higher with the BPWDS diet than with the C diet (C 1214 vs. BPWDS $1301 \mathrm{~g} \mathrm{~d}^{-1} ; p=0.10$ ), but the treatments had no significant effect on carcass gain, feed conversion or slaughter parameters. Only the BPWDS diet differed significantly from the C diet in DM (C 9.69 vs. BPWDS $10.38 \mathrm{~kg} \mathrm{DM} \mathrm{d}^{-1} ; p<0.01$ ) and energy intake (C 112.4 vs. BPWDS $120.3 \mathrm{MJ} \mathrm{d}^{-1} ; p<0.05$ ). The apparent organic matter digestibility (OMD) was $5 \%$ higher in the BPWDS diet than in the C diet ( $p$ $<0.001$ ), but the RSM and WDS diets did not differ from the C diet in OMD. The results indicate that the supply of protein in dairy bulls is most probably adequate with moderate digestible, well-preserved grass silage and barley-based concentrates when intake of digestible organic matter is high enough to support microbial protein synthesis in the rumen.
\end{abstract}

Key-words: Beef production, dairy bulls, protein supplementation, total mixed ration, barley protein, wet distillers' solubles 
Huuskonen, A. Need for protein supplementation in the diet of growing dairy bulls

\section{Introduction}

Beef production in Finland is based mainly on raising dairy bulls by feeding them grass silage and cereal grain-based concentrates. In some feeding experiments (Joki-Tokola 1991, Aronen et al. 1992, Aronen and Vanhatalo 1992a), partial replacement of cereal grains by protein feeds had a positive effect on live weight gain (LWG), while in others the effect was non-existent (Huhtanen et al. 1989, Aronen 1990, Huuskonen et al. 2007a). The improved LWG may have been related either to an increased uptake of amino acids or to improved digestibility of the diet and thereby increased feed intake (Aronen and Vanhatalo 1992b). The Finnish protein evaluation system for ruminants (MTT 2006) takes into account both the nitrogen required for rumen microbes and the supply of amino acids to the animal. The amino acids are of microbial or feed origin. Grass silage is usually cut at an early stage of maturity to obtain silage of high digestibility and, consequently, also the crude protein $(\mathrm{CP})$ content of the grass is high. Grass silage $\mathrm{CP}$ is characterized by rapid and high (80-90\%) degradability in the rumen, which usually results in an excess of rumen-degradable protein for rumen microbes in beef cattle (Aronen 1992). Therefore, the protein supplement, if needed, should have clearly lower rumen degradability of CP compared to grass silage. In Finland, rapeseed meal (RSM) is the most important protein feed used in concentrates for cattle. According to Harazim et al. (2002) effective degradability of CP in RSM was determined to amount to $68.1 \%$. Similarly, CP degradability of canola meal was $67.3 \%$ in the experiment of Boila and Ingalls (1992). According to the literature, a protein supplement may have a positive effect on the daily growth rate of growing cattle when the gain without protein supplementation is low, for example, with low-digestibility silage (Steen 1988) or hay (Aronen 1990, Hennessy et al. 2000), with extensively fermented silage (Jaakkola et al. 1990) or with small amounts of concentrate supplements (Pike et al. 1988). However, it is not clear how low grass silage digestibility should be, for protein supplementation to have a positive effect on the LWG of dairy bulls. There exists no data on the performance of dairy bulls fed with or without protein supplement and moderate digestible grass silage in total mixed ration (TMR) feeding.

Nowadays many beef producers use protein supplements with grass silage-barley-based feedings in Finland (Harri Jalli, personal communication, LSO Foods Ltd., January 10, 2008) even though the price of RSM is very high compared to those of grain or forages. However, there are also some other protein supplements available. For example, an integrated production process of ethanol and starch from barley creates by-product fractions such as barley fibre (BF), wet distillers' solubles (WDS) and barley protein (BP) (Näsi 1988) that are often low-priced feeds. So it would be cost-effective if these by-products can replace grain or more expensive protein supplements in the feeding. With TMR feeding it is easy to use liquid by-products, like BP and WDS. These protein-rich products have been studied earlier in few separate feeding experiments with growing bulls. Root and Huhtanen (1998) reported that increasing WDS to the grass-silage-barley-based diet did not have a significant effect on the LWG of bulls. Huhtanen et al. (1989) and Aronen (1990) studied dried BP with growing cattle and, according to Aronen (1990), dried BP seems to be more suitable as a protein supplement for hay-based than for grass-silage-based diets. However, there exist no published results about liquid protein supplements from the barley-based integrated starchethanol process with TMR-fed dairy bulls. In addition, feeding extra protein increased the $\mathrm{N}$ and $\mathrm{P}$ excretion to the environment (Klopfenstein and Erickson 2002, Satter 2003). Also extra protein puts unnecessary load on the animal's metabolism because of increasing excretion of $\mathrm{N}$. Is there enough protein in the diet to support high growth without protein supplementation is an important question for Finnish beef producers. The present experiment was conducted to study the need for protein supplementation in the diet of growing dairy bulls fed a moderate digestible grass-silagebarley-based TMR. It was hypothesised that the animal performance is lower when protein supplement is not used in moderate digestible grass silage-barley-based TMR. 
Vol. 17 (2008): 109-120.

\section{Material and methods}

\section{Animals, diets and experimental design}

A feeding experiment with 24 Finnish Ayrshire bulls and 8 Holstein-Friesian bulls was conducted between March 2005 and February 2006 in the experimental barn of North Ostrobothnia Research Station of MTT Agrifood Research Finland (Ruukki, 644ㄴ ${ }^{\prime} \mathrm{N}, 25^{\circ} 15^{\prime} \mathrm{E}$ ). The experimental procedures were evaluated and approved by the Animal Care and Use Committee of MTT Agrifood Research Finland. All animals were purchased from local dairy farms. Before the beginning of the trial the animals received grass silage and concentrates (commercial pelleted calf starter, flattened barley and rapeseed meal). At the beginning of the present experiment the animals (initial live weight (LW) $272 \pm 28.5 \mathrm{~kg}$ and age $191 \pm 6.6$ days) were divided into eight blocks of four animals by LW and breed. Age was not taken into account in the blocking because of the small variation in age. The animals were housed in a tie-up barn and individually fed three times per day (at 0800, 1200 and $1800 \mathrm{~h}$ ). Refused feed was collected and measured at $0700 \mathrm{~h}$ daily. The bulls had free access to water from an open water bowl during the experiment.

The experiment included four treatments and each treatment was assigned to one randomly selected animal in each block. Basic TMR (grass silage (450 $\mathrm{g} \mathrm{kg}^{-1}$ dry matter (DM)), flattened barley grain (275) and BF (275)) was mixed in a mixer wagon (Junkkari Ltd., Ylihärmä, Finland) and fed to all bulls ad libitum (proportionate refusals as 5\%). In addition, protein supplements were mixed daily in the basic TMR individually for each bull so that the four treatments were:

1. control diet (C): no protein supplementation, but the bulls received barley supplementation (530 g DM per animal $\mathrm{d}^{-1}$ ) to ensure the same concentrate proportion and energy content for all four treatments

2. rapeseed meal (RSM) 530 g DM per animal d $^{-1}$
3. wet distillers' solubles (WDS) $600 \mathrm{~g} \mathrm{DM}$ per animal $\mathrm{d}^{-1}$

4. a mixture of barley protein $(90 \%$ from fresh weight) and wet distillers' solubles (10) (BPWDS) $480 \mathrm{~g} \mathrm{DM}$ per animal d $^{-1}$.

After supplementation the concentrate proportion of the diets was increased to $570-580 \mathrm{~g} \mathrm{~kg}^{-1}$ DM. Treatments 2-4 were isonitrogenous, since each protein supplement provided $170 \mathrm{~g} \mathrm{CP}$ per animal $\mathrm{d}^{-1}$ during the whole study. As compared with the $\mathrm{C}$ diet, the $\mathrm{CP}$ content of the concentrates in the other diets increased from 137 to $150 \mathrm{~g} \mathrm{~kg}^{-1}$ DM (9\%) on average during the experiment. All the bulls received a mineral supplement $(150 \mathrm{~g}$ per animal $\mathrm{d}^{-1}$ ) and a vitamin supplement (50 g per animal per week). Grass silage was direct-cut from a second-growth timothy (Phleum pratense) and meadow fescue (Festuca pratensis) sward and ensiled in bunker silos with a formic acidbased additive applied at a rate of 51 per tonne of fresh grass. Barley fibre is a fibrous product comprised mainly of the cell wall fraction of barley endosperm. The commercial BF (produced by Altia Ltd., Koskenkorva, Finland) included BF (950 $\left.\mathrm{g} \mathrm{kg}^{-1} \mathrm{DM}\right)$, wet distillers' solubles (25) and molasses (25). Wet distillers' solubles is the nonfermentable residue after distillation of ethanol, and BP is obtained as a result of removal of the protein fraction from the cereal cells by separation. A detailed description of the integrated starch-ethanol process and the by-products of the process are given by Näsi (1988).

\section{Measurements}

The animals were weighed on two consecutive days at the beginning of the experiment, and thereafter every 28 days. Before slaughter they were weighed on two consecutive days. The target carcass weight was $350 \mathrm{~kg}$, and the bulls were selected for slaughter based on LW and an assumed dressing proportion. The LWG was calculated as the difference between the means of initial and final weights. The estimated rate of carcass gain was calculated by assuming an initial carcass 
Huuskonen, A. Need for protein supplementation in the diet of growing dairy bulls

weight of 0.50 of initial LW which was used also in previous studies by Root and Huhtanen (1998) and Huuskonen et al. (2007b). Dressing proportions were calculated from the ratio of hot carcass weight to final LW. For conformation, development of carcass profiles, in particular the essential parts (round, back, shoulder), was taken into consideration according to the EUROP classification (E: excellent, U: very good, R: good, O: fair, P: poor), and for fat cover degree the amount of fat on the outside of the carcass and in the thoracic cavity was taken into account using a classification range from 1 to 5 (1: low, 2: slight, 3: average, 4 : high, 5: very high). Each level of conformation scale was subdivided into 3 sub-classes $(\mathrm{O}+, \mathrm{O}$, $\mathrm{O}-)$ to a transformed scale ranging from 1 to 15 , 15 being the best conformation (Commission of the European Communities 1982).

\section{Sample Analyses}

Silage samples were analysed for DM (determined at $105^{\circ} \mathrm{C}$ for $20 \mathrm{~h}$ ) at the beginning of the experiment and twice a week, thereafter for preparation of TMR. Silage sub-samples for chemical analyses were taken twice a week, pooled over periods of four weeks and stored at $-20^{\circ} \mathrm{C}$. Thawed samples were analysed for DM, ash, CP, NDF, ether extract, phosphorus $(\mathrm{P})$, silage fermentation quality $(\mathrm{pH}$, water-soluble carbohydrates, lactic and formic acids, volatile fatty acids, soluble and ammonia $\mathrm{N}$ content of $\mathrm{N}$ ) and digestible organic matter (DOM) in DM (D value). Concentrate sub-samples were collected weekly, pooled over periods of eight weeks and analysed for DM, ash, CP, NDF, ether extract and $\mathrm{P}$. The analyses of DM, ash, CP and NDF were made as described by Ahvenjärvi et al. (2000). The ether extracts were determined according to procedure 920.39 of AOAC (1990) after acid (HCL) hydrolysis. Phosphorus was determined using an ICP emission spectrophotometer (Thermo Jarrel Ash/Baird, Franklin, USA) as described by Luh Huang and Schulte (1985). The silage was analysed for fermentation quality by the methods described by Moisio and Heikonen
(1989) and for D value by the method described by Nousiainen et al. (2003).

Diet digestibility was determined for all animals when the bulls were $603 \pm 39 \mathrm{~kg} \mathrm{LW}$. Feed and faecal samples were collected twice a day (at 0700 and $1500 \mathrm{~h}$ ) during the collection period (5 d), pooled and stored frozen prior to analyses. Thawed samples were analyzed for DM, ash, CP and NDF as described above. Diet digestibility was determined using acid-insoluble ash (AIA) as an internal marker (Van Keulen and Young 1977). The AIA content of the samples was analysed according to the regulations of the European Commission (1971).

The metabolizable energy (ME) value of the silage was calculated as $0.16 \times \mathrm{D}$ value $(\mathrm{MAFF}$ 1981). The ME values of the concentrates were calculated as described by Schiemann et al. (1972) and MAFF (1984). The digestibility coefficients of concentrates were taken from the Finnish feed tables. The supply of amino acids absorbed from the small intestine (AAT) and protein balance in the rumen (PBV) were calculated according to the Finnish feed tables (MTT 2006).

\section{Statistical analysis}

The experiment was set up according to a randomized complete block design with animal as an experimental unit. The results are shown as least squares means, because the records from the excluded animal were not replaced. The data were subjected to analysis of variance using the SAS mixed model procedure. The model used was

$y_{i j}=\mu+B_{j}+P_{i}+e_{i j}$

where $\mu$ is the overall mean, $B_{j}$ is the random effect of block $(j=1, \ldots, 8), e_{i j}$ is the random error term and $P_{i}$ is the fixed effect of protein supplement. Differences between the diets were compared using an a priori test (Dunnett's test) so that comparison of the diets was based on the $\mathrm{C}$ diet. 
Vol. 17 (2008): 109-120.

\section{Results}

\section{Diets}

The contents of DM, OM, CP, ether extracts, NDF and calculated contents of ME, AAT and PBV of the feeds are given in Table 1 . The average $D$ value of silage was $653 \mathrm{~g} \mathrm{DOM} \mathrm{kg}^{-1} \mathrm{DM}$ and very close to the pre-planned $\mathrm{D}$ value (650). The fermentation characteristics of the silage were good as indicated by the low $\mathrm{pH}$ value and the low concentration of ammonia $\mathrm{N}$ and total acids. The $\mathrm{CP}$ content of $\mathrm{BP}$ was $13 \%$ higher than that of WDS and $8 \%$ higher than the CP content of RSM. The NDF content of RSM was clearly higher than that of BP or WDS. The calculated energy value of BP was $2.5-3.0 \%$ higher than the energy values of WDS or RSM. The calculated AAT content of WDS was $28 \%$ lower than that of RSM and $40 \%$ lower than the AAT content of BP. The calculated PBV content of WDS was clearly lower than that of RSM and BP. The P contents of protein supplements were clearly higher than those of silage, barley and BF (Table 1).

The average chemical compositions of TMR are presented in Table 2. The DM contents of the $\mathrm{C}$ and RSM rations were $6 \%$ higher than those of WDS and BPWDS rations, because WDS and BP were liquid feeds. The $\mathrm{CP}$ content of the $\mathrm{C}$ ration was $7 \%$ lower than that of the other rations. The $\mathrm{P}$ content of the $\mathrm{C}$ ration was $27 \%$ lower than that of the WDS ration and 15\% lower than the P content of the RSM and BPWDS rations. The energy content of all diets was $11.6 \mathrm{MJ} \mathrm{kg}^{-1} \mathrm{DM}$.

\section{Feed intake, diet digestibility and animal performance}

One animal (in RSM diet) was excluded from the study due to several occurrences of bloat. There

Table 1. Chemical composition and feeding values of concentrates and grass silage.

\begin{tabular}{|c|c|c|c|c|c|c|}
\hline & $\begin{array}{l}\text { Grass } \\
\text { silage }\end{array}$ & $\begin{array}{l}\text { Barley } \\
\text { grain }\end{array}$ & $\begin{array}{l}\text { Barley } \\
\text { fibre }\end{array}$ & $\begin{array}{l}\text { Barley } \\
\text { protein }\end{array}$ & $\begin{array}{l}\text { Wet distillers' } \\
\text { solubles }\end{array}$ & $\begin{array}{l}\text { Rapeseed } \\
\text { meal }\end{array}$ \\
\hline Number of samples & 11 & 5 & 5 & 5 & 5 & 5 \\
\hline Dry matter (DM), $\mathrm{g} \mathrm{kg}^{-1}$ feed & 228 & 879 & 920 & 202 & 320 & 880 \\
\hline \multicolumn{7}{|l|}{ In the $\mathrm{DM}, \mathrm{g} \mathrm{kg}^{-1}$} \\
\hline Organic matter (OM) & 937 & 977 & 963 & 946 & 871 & 913 \\
\hline Crude protein & 167 & 128 & 147 & 360 & 318 & 333 \\
\hline Neutral detergent fibre & 551 & 191 & 599 & 73 & 3 & 254 \\
\hline Ether extract & 35 & 24 & 63 & 60 & 55 & 42 \\
\hline Phosphorus & 2.7 & 3.8 & 3.6 & 9.4 & 16.0 & 10.8 \\
\hline Digestible OM in DM, $\mathrm{g} \mathrm{kg}^{-1} \mathrm{DM}$ & 653 & $\mathrm{ND}^{\mathrm{a}}$ & ND & ND & ND & ND \\
\hline Metabolizable energy, $\mathrm{MJ} \mathrm{kg}^{-1} \mathrm{DM}$ & 10.5 & 13.1 & 11.5 & 13.2 & 12.9 & 12.8 \\
\hline $\mathrm{AAT}^{\mathrm{b}}, \mathrm{g} \mathrm{kg}^{-1} \mathrm{DM}$ & 83 & 106 & 98 & 164 & 117 & 150 \\
\hline $\mathrm{PBV}^{\mathrm{c}}, \mathrm{g} \mathrm{kg}^{-1} \mathrm{DM}$ & 25 & -39 & -21 & 127 & 54 & 110 \\
\hline \multicolumn{7}{|l|}{ Fermentation quality of silage } \\
\hline $\mathrm{pH}$ & 4.0 & & & & & \\
\hline Volatile fatty acids, $\mathrm{g} \mathrm{kg}^{-1} \mathrm{DM}$ & 20 & & & & & \\
\hline Lactic + formic acid, $\mathrm{g} \mathrm{kg}^{-1} \mathrm{DM}$ & 61 & & & & & \\
\hline Water-soluble carbohydrates, $\mathrm{g} \mathrm{kg}^{-1} \mathrm{DM}$ & 20 & & & & & \\
\hline \multicolumn{7}{|l|}{ In total nitrogen, $\mathrm{g} \mathrm{kg}^{-1}$} \\
\hline Ammonia $\mathrm{N}$ & 60 & & & & & \\
\hline Soluble N & 490 & & & & & \\
\hline
\end{tabular}

${ }^{\mathrm{a}}$ Not determined. ${ }^{\mathrm{b}}$ Amino acids absorbed from small intestine. ${ }^{\mathrm{c}}$ Protein balance in the rumen. 
Huuskonen, A. Need for protein supplementation in the diet of growing dairy bulls

Table 2. Chemical composition and feeding values of total mixed rations.

\begin{tabular}{|c|c|c|c|c|}
\hline & \multicolumn{4}{|c|}{ Total mixed ration $^{\mathrm{a}}$} \\
\hline & $\mathrm{C}$ & RSM & WDS & BPWDS \\
\hline Dry matter (DM), $\mathrm{g} \mathrm{kg}^{-1}$ & 402 & 402 & 383 & 373 \\
\hline \multicolumn{5}{|l|}{ Composition of DM, $\mathrm{g} \mathrm{kg}^{-1}$} \\
\hline Organic matter & 956 & 953 & 950 & 955 \\
\hline Crude protein & 150 & 160 & 161 & 161 \\
\hline Ether extract & 40 & 42 & 43 & 43 \\
\hline Neutral detergent fibre & 461 & 453 & 437 & 444 \\
\hline Phosphorus & 3.3 & 3.8 & 4.2 & 3.8 \\
\hline Metabolizable energy, $\mathrm{MJ} \mathrm{kg}^{-1} \mathrm{DM}$ & 11.59 & 11.57 & 11.58 & 11.59 \\
\hline $\mathrm{AAT}^{\mathrm{b}}, \mathrm{g} \mathrm{kg}^{-1} \mathrm{DM}$ & 94 & 96 & 95 & 97 \\
\hline $\mathrm{PBV}^{\mathrm{c}}, \mathrm{g} \mathrm{kg}^{-1} \mathrm{DM}$ & -7 & 0 & -2 & 1 \\
\hline
\end{tabular}

${ }^{a}$ The control diet (C) included only basic ration (grass silage, barley and barley fibre), without protein supplementation. The three isonitrogenous experimental diets were rapeseed meal (RSM), wet distillers' solubles (WDS) and a mixture of barley protein ( $90 \%$ of fresh weight) and wet distillers' solubles (10) (BPWDS). ${ }^{\mathrm{b}}$ Amino acids absorbed from small intestine. ${ }^{\mathrm{c}}$ Protein balance in the rumen.

was no reason to suppose that the diet had caused this problem. The average feed DM, ME and protein intakes during the experiment are presented in Table 3. The total DM intake (DMI) $(p<0.01)$ and ME intake (MEI) $(p<0.01)$ were $7 \%$ higher in the BPWDS diet than in the $\mathrm{C}$ diet, and DMI kg-1 $\mathrm{W}^{0.75}$ and MEI kg-1 $\mathrm{W}^{0.75}$ tended to be higher $(p=$ 0.06) in the BPWDS diet than in the $\mathrm{C}$ diet. Also in the RSM diet DMI kg-1 $\mathrm{W}^{0.75}$ and MEI kg-1 $\mathrm{W}^{0.75}$ tended to be higher $(p=0.08)$ than in the $\mathrm{C}$ diet. There were no significant differences in any feed or energy intake parameters between treatments $\mathrm{C}$ and WDS. In CP intake, all isonitrogenous diets differed significantly from the $\mathrm{C}$ diet, but in AAT intake only the BPWDS diet differed from the $\mathrm{C}$ diet (AAT intake was 9.7\% higher than that in the $\mathrm{C}$ diet; $p<0.001)$.

The apparent organic matter digestibility (OMD) was 5\% higher in the BPWDS diet than in the $\mathrm{C}$ diet $(p<0.001)$, but RSM and WDS diets did not differ from the $\mathrm{C}$ diet in OMD (Table 3). The CP digestibility was significantly higher in the RSM and BPWDS diets than in the $\mathrm{C}$ diet $(p<$ $0.001)$. The digestibility of NDF tended to be lower in the BPWDS diet than in the $\mathrm{C}$ diet $(p=0.06)$. There were no significant differences in digestibility parameters between treatments C and WDS.

The mean final LW of the bulls was $666 \mathrm{~kg}$ (Table 4). The final LW of the bulls fed BPWDS diet was 5\% higher compared with the bulls fed C $\operatorname{diet}(p<0.01)$. The LWG of the bulls tended to be higher with the BPWDS diet than with the $\mathrm{C}$ diet $(p=0.10)$, but treatments had no significant effect on carcass gain or feed conversion rates. The average (all treatments) carcass weight was $344 \mathrm{~kg}$ and very close to the pre-planned carcass weight. The carcass weight tended to be higher in the BPWDS diet than in the $\mathrm{C} \operatorname{diet}(p=0.06)$. Treatments had no significant effect on the dressing proportion, carcass conformation or fat classification (Table 4).

\section{Discussion}

\section{Feed intake and diet digestibility}

In the present experiment the RSM diet did not differ from the $\mathrm{C}$ diet in DMI $\left(\mathrm{kg} \mathrm{DM} \mathrm{d}^{-1}\right)$ or MEI $\left(\mathrm{MJ} \mathrm{d}^{-1}\right)$, which is in accordance with the results of Huuskonen et al (2007a) on dairy bulls fed grass silage-barley grain-based TMR. In some earlier studies on growing dairy bulls with separate feeding the RSM supplementation increased the intake of hay (Aronen 1990) or grass silage (Aronen 1990, Aronen and Vanhatalo 1992a, Aronen et al. 1992) but, for example, Huhtanen et al. (1985, 1989) 
Vol. 17 (2008): 109-120.

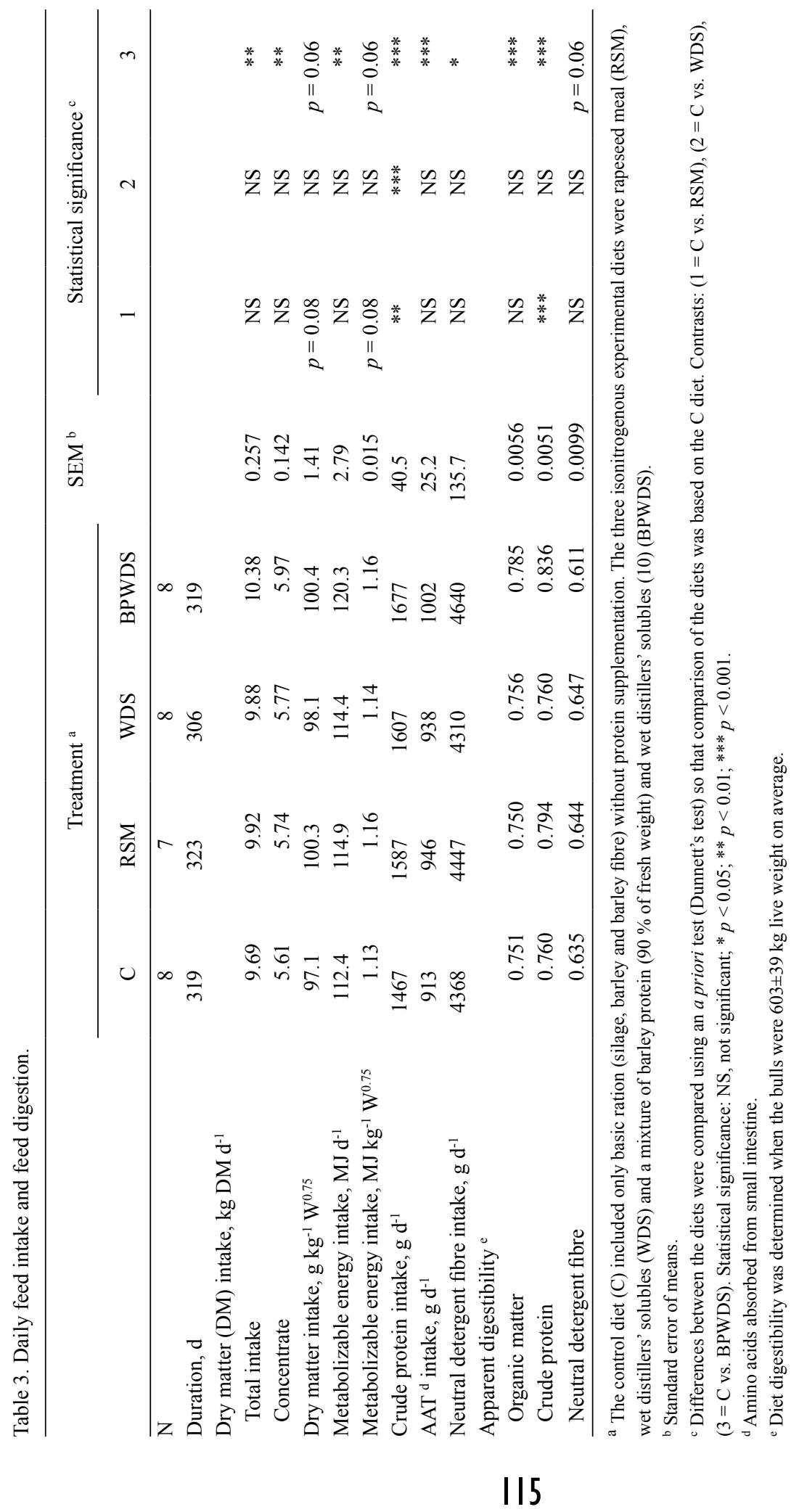


Huuskonen, A. Need for protein supplementation in the diet of growing dairy bulls

Table 4. Live weight, daily gain, feed conversion rate and slaughter data.

\begin{tabular}{|c|c|c|c|c|c|c|c|c|}
\hline & \multicolumn{4}{|c|}{ Treatment $^{\mathrm{a}}$} & \multirow[t]{2}{*}{ SEM $^{b}$} & \multicolumn{3}{|c|}{ Statistical significance $^{c}$} \\
\hline & $\mathrm{C}$ & RSM & WDS & BPWDS & & 1 & 2 & 3 \\
\hline Initial live weight, $\mathrm{kg}$ & 271 & 261 & 275 & 279 & 14.5 & NS & NS & NS \\
\hline Final live weight, $\mathrm{kg}$ & 655 & 656 & 661 & 691 & 12.5 & NS & NS & $* *$ \\
\hline Live weight gain (LWG), $\mathrm{g} \mathrm{d}^{-1}$ & 1214 & 1229 & 1265 & 1301 & 44.6 & NS & NS & $p=0.10$ \\
\hline Carcass gain, $\mathrm{g} \mathrm{d}^{-1}$ & 653 & 660 & 696 & 699 & 27.0 & NS & NS & NS \\
\hline \multicolumn{9}{|l|}{ Feed conversion } \\
\hline $\mathrm{MJ} \mathrm{kg}{ }^{-1} \mathrm{LWG}$ & 93 & 94 & 91 & 93 & 2.5 & NS & NS & NS \\
\hline $\mathrm{AAT}^{\mathrm{d}}, \mathrm{g} \mathrm{kg}^{-1} \mathrm{LWG}$ & 756 & 773 & 744 & 774 & 20.9 & NS & NS & NS \\
\hline $\mathrm{MJ} \mathrm{kg}^{-1}$ carcass gain & 173 & 175 & 166 & 174 & 6.1 & NS & NS & NS \\
\hline AAT, $\mathrm{g} \mathrm{kg}^{-1}$ carcass gain & 1405 & 1439 & 1360 & 1448 & 50.1 & NS & NS & NS \\
\hline \multicolumn{9}{|l|}{ Slaughter data } \\
\hline Carcass weight, $\mathrm{kg}$ & 337 & 338 & 344 & 355 & 7.9 & NS & NS & $p=0.06$ \\
\hline Dressing proportion, $\mathrm{g} \mathrm{kg}^{-1}$ & 515 & 514 & 520 & 514 & 5.9 & NS & NS & NS \\
\hline EUROP conformation $^{\mathrm{e}}$ & 4.4 & 4.62 & 4.1 & 5.0 & 0.41 & NS & NS & NS \\
\hline EUROP fat classification ${ }^{\mathrm{f}}$ & 2.9 & 3.3 & 3.0 & 3.3 & 0.21 & NS & NS & NS \\
\hline \multicolumn{9}{|c|}{$\begin{array}{l}\text { a The control diet }(\mathrm{C}) \text { included only basic ration (silage, barley and barley fibre) without protein supplementation. The three isonitroge- } \\
\text { nous experimental diets were rapeseed meal (RSM), wet distillers' solubles (WDS) and a mixture of barley protein }(90 \% \text { of fresh weight) } \\
\text { and wet distillers' solubles }(10 \%) \text { (BPWDS). } \\
\text { b Standard error of means. } \\
\text { c Differences between the diets were compared using an a priori test (Dunnett's test) so that comparison of the diets was based on the C } \\
\text { diet. Contrasts: ( } 1=\mathrm{C} \text { vs. RSM), }\left(2=\mathrm{C} \text { vs. WDS), }\left(3=\mathrm{C} \text { vs. BPWDS). Statistical significance: NS, not significant; }{ }^{*} p<0.05 ; * * p<0.01\right.\right. \\
*_{* *}^{* *} p<0.001 \text {. }\end{array}$} \\
\hline
\end{tabular}

reported no effect on grass silage intake. On TMR feeding the animals cannot increase only their silage intake and in the study of Huuskonen et al. (2007a) RSM supplementation had no effect on the total DMI. In agreement with Huuskonen et al. (2007a), RSM supplementation had no effect on OMD in the present trial, which is in line with the lack of significant effect on DMI. Inversely, the CP digestibility was slightly higher with the RSM diet than with the $\mathrm{C}$ diet, which is in accordance with the results of Huhtanen et al. (1985), Aronen and Vanhatalo (1992), Aronen et al. (1992) and Huuskonen et al. (2007a). Some of the increased apparent digestibility of $\mathrm{CP}$ on the protein-supplemented diets may have reflected the better digestibility of protein, while most of the increase is only apparent, being attributable to the decreased proportion of faecal metabolic nitrogen recovered in faeces with increasing CP content (Minson 1982).
Increased total daily DMI $\left(\mathrm{kg} \mathrm{DM} \mathrm{d}^{-1}\right)$ in the BPWDS diet compared with the $\mathrm{C}$ diet was reflected also as larger daily ME, AAT and NDF intakes. Reasons for higher intake are not totally clear. Increased total DMI $\left(\mathrm{kg} \mathrm{DM} \mathrm{d}{ }^{-1}\right)$ in the BPWDS diet can be partly explained by higher LW of BPWDS bulls. Although there was no significant differences in initial LW, the final LW of BPWDS bulls was slightly higher than that of C bulls. The difference in DMI between the $\mathrm{C}$ and BPWDS diets was greater in DMI measured as $\mathrm{kg} \mathrm{d}^{-1}(7.1 \%)$ than in DMI measured as $\mathrm{g} \mathrm{kg}^{-1}$ $\mathrm{W}^{0.75}(3.4 \%)$, which supports the previous statement. The good palatability of BPWDS may also partly explain the increased DMI in the BPWDS diet. Subjective observations during the experiment support this conclusion, and Aronen (1990) also reported that the palatability of BP was good in his study with growing bulls. The CP digest- 
Vol. 17 (2008): 109-120.

ibility was clearly higher with the BPWDS diet than with the $\mathrm{C}$ diet, which probably increased the endogenous urinary nitrogen exrection in the BPWDS diet. Because the digestibility of NDF tended to be lower with the BPWDS diet than with the $\mathrm{C}$ diet, improved OMD manifests in non-fibre fractions.

Compared with the $\mathrm{C}$ diet, WDS increased the CP intake of the bulls, but did not affect DMI, MEI or AAT intake. There were no differences in diet digestibility between the $\mathrm{C}$ and WDS diets, which may partly explain why no difference was observed in DMI. Also Root and Huhtanen (1998) reported that the inclusion of distillers' solubles in the diet of growing bulls had no significant effect on silage intake, total DMI as well as AAT or energy intake with separate feeding. Huhtanen (1992) found that despite the increased $\mathrm{N}$ intake by the inclusion of distillers' solubles to the diet, the total $\mathrm{N}$ or non-ammonia $\mathrm{N}$ flow in the duodenum was not changed in growing bulls, which was due to the high rumen degradability of protein in distillers' solubles. Therefore, it can be assumed that due to high rumen degradability of protein, WDS increased little the amino acid supply, but increased the amount of ammonia in the rumen.

The P content of all protein supplements (especially WDS) was high relative to silage, barley and BF. However, according to the Finnish feeding recommendations (MTT 2006), the supply of $\mathrm{P}$ was sufficient also in the $\mathrm{C}$ diet throughout the feeding experiment. This indicates that feeding extra protein increased the $\mathrm{P}$ excretion to the environment, because increasing the $\mathrm{P}$ content of the diet will lead to higher P content of manure (Satter 2003). Extra nitrogen also causes significant water pollution when discharged into surface water through runoff or deposited in water from aerial emissions (e.g. Klopfenstein and Erickson 2002). Decreasing dietary protein inputs in feeding could potentially decrease environmental concerns related to air and water quality (Cole et al. 2003). Increased P excretion should be avoided by using mineral feeds of low $\mathrm{P}$ content together with these by-products.

\section{Animal performance}

In all treatments in the present study the performance of the bulls was good (LWG $1254 \mathrm{~g} \mathrm{~d}^{-1}$, on average). Also LWG in the $\mathrm{C} \operatorname{diet}\left(1214 \mathrm{~g} \mathrm{~d}^{-1}\right)$ was good compared with our earlier study with dairy bulls fed grass silage-barley-based diets (1168 g $\mathrm{d}^{-1}$, Huuskonen et al. 2007a). Albeit the LWG of the bulls fed BPWDS diet tended to be higher compared with the bulls fed $\mathrm{C}$ diet, none of the protein supplements had any significant effect on carcass gain or feed conversion in the present experiment. The effect of protein supplementation on daily gain on grass silage-barley-based feedings has been rather inconsistent in various experiments. Much of this variation can be attributed to the differences in the quality of the silage offered. Waterhouse et al. (1985) reported that finishing Friesian steers are likely to respond to supplementary protein in barley-based concentrates where grass silage digestibility is low (in vitro digestibility below 0.65 ). With poorly preserved silage the response in animal performance to protein supplementation is greater than with well-preserved silage (Steen 1988, Jaakkola et al. 1990). There may be differences also between extensively and restrictively fermented silages, which both may be well-preserved, because Jaakkola et al. (1990) reported that the response to fish meal was greater when enzyme solution (cellulose-glucose oxidase) was used as a silage additive instead of formic acid.

The responses to protein supplements seem to be related also to the level of concentrate supplement, greater effects being observed with small amounts of concentrates (Pike et al. 1988). The rate of protein synthesis improved with moderate addition of barley-based concentrate to a silage diet (Thomas et al. 1980, Rooke et al. 1985), whereas further substitution gradually reduced the efficiency of synthesis (Harstad and Vik-Mo 1985). Hagemeister et al. (1980) reported a tendency towards lower protein synthesis with rations containing very low (0-20\%) or high (70-100\%) proportions of concentrate. In the present study, the silage was of good quality in terms of fermentation characteristics (low concentrations of fermentation acids and ammonia $\mathrm{N}$ ) and it was 


\section{Huuskonen, A. Need for protein supplementation in the diet of growing dairy bulls}

treated with formic acid-based silage additive. The $\mathrm{D}$ value of the silage was moderate $(653 \mathrm{~g}$ $\mathrm{kg}^{-1} \mathrm{DM}$, on average) and the CP content quite high (167 $\left.\mathrm{g} \mathrm{kg}^{-1} \mathrm{DM}\right)$, which maintained a high intake of DOM when fed with barley-based concentrate $\left(570-580 \mathrm{~g} \mathrm{~kg}^{-1} \mathrm{DM}\right)$. The lack of response (RSM and WDS) or only minor response (BPWDS) to protein supplementation may therefore be attributable to high intake of DOM, because the microbial protein synthesis can be assumed to have been relatively high. In accordance with many earlier studies (e.g. Huhtanen et al. 1985, 1989, Aronen 1990, Root and Huhtanen 1998, Huuskonen et al. 2007a), protein supplements had no significant effect on dressing proportion, carcass conformation or fat classification in our study. In conclusion, our results indicate that the supply of protein in dairy bulls is most probably adequate with moderate digestible, well-preserved grass silage and barley-based concentrates.

Acknowledgements. This study was partially funded by the Employment and Economic Development Centre for Northern Ostrobothnia, Altia Ltd. and A-Farmers Ltd. The authors wish to thank Mr. Lauri Jauhiainen for advice on statistical analyses. The authors wish to express their thanks also to Mr. Matti Huumonen and his personnel for technical assistance and care of the experimental animals. The personnel at Animal Production Research in Jokioinen is also thanked for conducting the laboratory analyses. The evaluation of the manuscript by Dr. Seija Jaakkola is warmly acknowledged.

\section{References}

Ahvenjärvi, S., Vanhatalo, A., Huhtanen, P. \& Varvikko, T. 2000. Determination of reticulo-rumen and whole stomach digestion in lactating cows by omasal canal and duodenal sampling. British Journal of Nutrition 83: 67-77.

AOAC 1990. Official Methods of Analysis. 15th edition. Associations of Official Analytical Chemists, Arlington, VA. 1298 p.

Aronen, I. 1990. Barley protein and rapeseed meal as protein supplements for growing cattle. Acta Agriculturae Scandinavica 40: 297-307.

Aronen, I., 1992. Quality of Supplementary Feed Protein for Growing Cattle. Academic dissertation. Faculty of Agriculture and Forestry of the University of Helsinki, Helsinki, Finland. 46 p.
Aronen, I., Toivonen, V., Ketoja, E. \& Öfversten, J. 1992. Beef production as influenced by stage of maturity of grass for silage and level and type of supplementary concentrates. Agricultural Science in Finland 1: 441-460.

Aronen, I. \& Vanhatalo, A. 1992a. Heat-moisture treatment of rapeseed meal: effect on diet digestion, voluntary grass silage intake and growth of Ay-bulls. Acta Agriculturae Scandinavica, Section A, Animal Science 42: $157-166$.

Aronen, I. \& Vanhatalo, A. 1992b. Rumen fermentation, diet digestion and microbial protein synthesis in growing heifers fed grass silage diets with or without concentrate supplementation. Agricultural Science in Finland 1: 177-188.

Boila, J.R. \& Ingalls, R.J. 1992. In situ rumen digestion and escape of dry matter, nitrogen and amoni acids in canola meal. Canadian Journal of Animal Science 72: 891-901.

Cole, N.A., Greene, L.W., McCollum, F.T., Montgomery, T. \& McBride, K.W. 2003. Influence of oscillating dietary crude protein concentration on performance, acid-base balance, and nitrogen excretion of steers. Journal of Animal Science 81: 2660-2668.

Commission of the European Communities 1982. Commission of the European Communities (Beef Carcass Classification) Regulations. Council Regulations 1358/80, 1208/81, 1202/82. Commission Regulations 2938/81, 563/82, 1557/82, Brussels.

European Commission 1971. Commission Directive $71 / 250 /$ EEC. Determination of ash which is insoluble in hydrochlorid acid. Official Journal No L 155/13: 30-31 (Method B).

Hagemeister, H., Lüpping, W. \& Kaufmann, W. 1980. Microbial protein synthesis and digestion in the high-yielding dairy cow. In: Haresign, W. (ed.). Recent Advances in Animal Nutrition - 1980. Butterworths, London, UK. p. 67-84.

Harazim, J., Třináctý, J. \& Homolka, P. 2002. Degradability and intestinal digestibility of crude protein and amino acids of extracted rapeseed meal. Czech Journal of Animal Science 47: 50-56.

Harstad, O.M. \& Vik-Mo, L. 1985. Estimation of microbial and undegraded protein in sheep on grass silage based diets. Acta Agriculturae Scandinavica, Supplement 25: 37-48.

Hennessy, D.W., Williamson, P.J. \& Darnell, R.E. 2000. Feed intake and liveweight responses to nitrogen and/ or protein supplements by steers of Bos taurus, Bos indicus and Bos taurus $\mathrm{x}$ Bos indicus breed types offered a low quality grass hay. Journal of Agricultural Science, Cambridge 135: 35-45.

Huhtanen, P. 1992. The effects of barley vs. barley fibre with or without distillers' solubles on site and extent of nutrient digestion in cattle fed grass-silage-based diet. Animal Feed Science and Technology 36: 319-337.

Huhtanen, P., Näsi, M. \& Khalili, H. 1989. By-products from integrated starch-ethanol production from barley in the diets of growing cattle. Journal of Agricultural Science in Finland 61: 451-462.

Huhtanen, P., Poutiainen, E. \& Mikkola, T. 1985. The effect of supplementation of grass silage with rapeseed meal or Gasol-treated barley on the performance of 


\section{AGRICULTURAL AND FOOD SCIENCE}

Vol. 17 (2008): 109-120.

growing cattle. Journal of Agricultural Science in Finland 57: 75-84.

Huuskonen, A., Khalili, H. \& Joki-Tokola, E. 2007a. Effects of three different concentrate proportions and rapeseed meal supplement to grass silage on animal performance of dairy breed bulls with TMR feeding. Livestock Science 110: 154-165.

Huuskonen, A., Khalili, H. \& Joki-Tokola, E. 2007b. Effects of replacing different proportions of barley grain by barley fibre on performance of dairy bulls. Agricultural and Food Science 16: 232-244.

Jaakkola, S., Huhtanen, P. \& Vanhatalo, A. 1990. Fermentation quality of grass silage treated with enzymes or formic acid and nutritive value in growing cattle fed with or without fish meal. Acta Agriculturae Scandinavica 40: 403-414.

Joki-Tokola, E. 1991. Lihaluurehujauho ja rypsirouhe sonnien valkuaisrehuna. Koetoiminta ja käytäntö 48: 64 .

Klopfenstein, T.J. \& Erickson, G.E. 2002. Effects of manipulation of protein and phosphorus nutrition of feedlot cattle on nutrient management and the environment. Journal of Animal Science 80 (E. Supplement 2): E106-E114.

Luh Huang, C.-Y. \& Schulte, E.E. 1985. Digestion of plant tissue for analysis by ICP emission spectrometry. Communications in Soil Science and Plant Analyses 16: 943-958.

MAFF 1981. Animal Science 1979. ADAS Reference Book 254. Ministry of Agriculture, Fisheries and Food. Her Majesty's Stationery Office, London. 103 p.

MAFF 1984. Energy allowances and feeding systems for ruminants. ADAS Reference Book 433. Ministry of Agriculture, Fisheries and Food. Her Majesty's Stationary Office, London. $85 \mathrm{p}$.

Minson, D.J. 1982. Effect of chemical composition on feed digestibility and metabolizable energy. Nutrition Abstracts and Reviews 52: 591-615.

Moisio, T. \& Heikonen, M. 1989. A titration method for silage assessment. Animal Feed Science and Technology 22: 341-353.

MTT 2006. Rehutaulukot ja ruokintasuositukset (Feed tables and feeding recommendations) [online]. Agrifood Research Finland, Jokioinen. Published 14.2.2006, [cited 7.9.2007]. Available at: http://www.agronet.fi/rehutaulukot/. URN:NBN:fi-fe20041449.
Näsi, M. 1988. Evaluating barley feed fractions from integrated ethanol-starch production in diets of ruminants. Journal of Agricultural Science in Finland 60: 701-709.

Nousiainen, J., Rinne, M., Hellämäki, M. \& Huhtanen, P. 2003. Prediction of the digestibility of the primary growth of grass silages harvested at different stages of maturity from chemical composition and pepsin-cellulase solubility. Animal Feed Science and Technology 103: 97-111.

Pike, I.H., Smith, G. \& Miller, E.L. 1988. An evaluation of fish meal as a protein supplement for beef cattle. Proceedings of the VII World Conference in Animal Production. p. 427.

Rooke, J.A., Brett, P.A., Overend, M.A. \& Armstrong, D.G. 1985. The energetic efficiency of rumen microbial protein synthesis in cattle given silage-based diets. Animal Feed Science and Technology 13: 255-267.

Root, T. \& Huhtanen, P. 1998. Barley fibre and wet distillers' solubles in the diet of growing cattle. Agricultural and Food Science in Finland 7: 357-366.

Satter, L.D. 2003. Phosphorus management in cattle production systems. In: Garnsworthy, P.C., Wiseman, J. (Eds.). Recent Advances in Animal Nutrition 2003. Nottingham University Press. p. 158-173.

Schiemann, R., Nehring, K., Hoffmann, L., Jentsch, W. \& Chudy, A. 1972. Energetische Futterbewertung und Energienormen. VEB Deutcher Landwirtschafsverlag Berlin, Germany. 344 p.

Steen, R.W.J. 1988. The effect of supplementing silagebased diets with soya bean and fish meals for finishing beef cattle. Animal Production 46: 43-51.

Thomas, P.C., Kelly, N.C., Chamberlain, D.G. \& Wait, M.K. 1980. The nutritive value of silages. Digestion of organic matter, gross energy and carbohydrate constituents in the rumen and intestines of sheep receiving diets of grass silage or grass silage and barley. British Journal of Nutrition 43: 481-489.

Van Keulen, J. \& Young, B.A. 1977. Evaluation of acid-insoluble ash as a marker in ruminant digestibility studies. Journal of Animal Science 44: 282-287.

Waterhouse, A., Laird, R. \& Arnot, D.P. 1985. Responses to protein supplements in silage-fed finishing steers: effects of silage quality and supplement type. Animal Production 40: 538 (Abstract). 
Huuskonen, A. Need for protein supplementation in the diet of growing dairy bulls

\title{
SELOSTUS
}

\section{Maitorotuisten sonnien lisävalkuaisen tarve nurmisäilörehuun ja ohraan perustuvalla seosrehuruokinnalla}

\author{
Arto Huuskonen, Hannele Khalili ja Erkki Joki-Tokola \\ MTT Kotieläintuotannon tutkimus
}

Tutkimuksen tavoitteena oli selvittää maitorotuisten sonnien lisävalkuaisen tarvetta, kun eläimiä ruokitaan keskinkertaisesti sulavaan nurmisäilörehuun (tutkimuksessa oli tavoitteena D-arvo 65) ja ohrapohjaiseen väkirehuun perustuvalla seosrehulla. Koe toteutettiin 32 maitorotuisella sonnilla (paino kokeen alussa $272 \mathrm{~kg}$ ja lopussa $666 \mathrm{~kg}$ ) ja neljällä erilaisella koeruokinnalla. Koeruokinnat erosivat toisistaan valkuaisruokinnan koostumuksen osalta. Kontrolliruokinta (C) sisälsi syyssadosta korjattua nurmisäilörehua (toteutunut D-arvo $65,3)$ (45\% kuiva-aineesta), ohraa (27.5) ja ohrarehua (27.5) ilman valkuaislisäystä. Kolme valkuaislisäyksen sisältänyttä koedieettiä olivat (1) rypsirouhe (RSM), (2) tiivistetty tärkkelysrankki (WDS) ja (3) ohravalkuaisrehun $(90 \%$ tuorepainosta) ja tiivistetyn tärkkelysrankin $(10 \%)$ seos (BPWDS). Kaikilla kolmella valkuaislisäyksen sisältäneellä ruokinnalla raakavalkuaislisäys oli $170 \mathrm{~g} \mathrm{~d}^{-1}$ eläintä kohti, jolloin väkirehun raakavalkuaispitoisuus nousi $9 \%$ kontrolliruokintaan verrattuna. Kaikki eläimet ruokittiin vapaasti seosrehulla. Dieetin energiasisältö oli sama kaikilla koekäsittelyillä (11.6
$\mathrm{MJ} \mathrm{kg}^{-1} \mathrm{ka}$ ). Ainoastaan BPWDS-ruokinta erosi merkitsevästi C-ruokinnasta kuiva-aineen syönnin (C 9.69 vs. BPWDS $10.38 \mathrm{~kg} \mathrm{ka} \mathrm{d}^{-1} ; p<0.01$ ) ja energian saannin (C 112.4 vs. BPWDS $120.3 \mathrm{MJ} \mathrm{d}^{-1} ; p<0.05$ ) osalta. Orgaanisen aineen näennäinen in vivo -sulavuus oli $5 \%$ korkeampi BPWDS-dieetillä C-dieettiin verrattuna ( $p<$ 0.001), mutta RSM- ja WDS-dieeteillä sulavuudet eivät eronneet merkitsevästi C-dieetistä. Ruokinnalla ei ollut tilastollisesti merkitsevää vaikutusta sonnien nettokasvuun, rehun hyväksikäyttöön eikä ruhon teuraslaatuun, mutta eläinten päiväkasvu oli BPWDS-dieetillä hieman kontrolliruokintaa korkeampi (C 1214 vs. BPWDS $\left.1301 \mathrm{~g} \mathrm{~d}^{-1} ; p=0.10\right)$. Sen sijaan RSM ja WDS eivät eronneet tilastollisesti merkitsevästi kontrolliruokinnasta päiväkasvun osalta. Tutkimuksen perusteella sulavuudeltaan keskinkertaista nurmisäilörehua käytettäessä valkuaislisälle ei näytä tulevan merkittävää tuotosvastetta yli puolen vuoden ikäisten maitorotuisten sonnien seosrehuruokinnassa, jos säilörehu on säilönnälliseltä laadultaan hyvää ja seoksessa käytetään väkirehua yli puolet kuiva-aineesta. 